\title{
Corruption in Lampung Local Election
}

\author{
${ }^{1}$ ROBI CAHYADI KURNIAWAN, ${ }^{2}$ ARIZKA WARGANEGARA, \\ ${ }^{3}$ BUDI KURNIAWAN. ${ }^{4}$ HIMAWAN INDRAJAT \\ $1,2,3,4$ Social \& Political Science Faculty, University of Lampung, Bandar Lampung, Indonesa \\ Correspondence author: robicahyadi9@gmail.com
}

\begin{abstract}
Local elections (pilkada) in Indonesia have many impacts, both positive and negative. Positive impact means local election is the implementation of direct democracy. Whereas, one of the negative impacts is the number of direct elections for regional heads that has led to the phenomenon of widespread corruption by regional heads (Kepada Daerah). In Lampung Province, eight (8) regional heads did corruption; four (4) of them caught red-handed with hand-catching operations (OTT) by the Corruption Eradication Commission (KPK). The purpose of this study is to analyze the phenomenon of corruption in regional elections in Lampung Province. This research uses qualitative methods with a descriptive approach. There are three (3) main factors influence corruption: first, anthropological factor, namely strong desire to rule; second, economic factor, namely the desire to obtain financial benefits from the results of power; third, sociological factors, such as the influence of family environment, social and political position status. The dominant factor is the economic factor due to the high political costs and large number of regulatory "loopholes" that can be manipulated for corruption. The high political costs are also caused by money politics.
\end{abstract}

Keywords: Corruption, Money Politics, Local Election

\section{Introduction}

Following the reformation era after the 1998 economic crisis, Indonesia has changed its previous general elections from indirect to direct mechanisms. As a result, general elections have become more democratic and decentralized. At the regional level, local autonomy as a manifestation of regional accountability has become an anomaly, especially in the management of regional funds, thus becoming a new area for corruption in some local governments. (Sudana, 2006: 150).

Based on researchers investigation, there is number of corruption cases by regional head occurred in Indonesia, which is 104 cases in 2019. The corruption cases consisted of 62 cases committed by the Regent (bupati), 23 cases by the Mayor, 15 cases by the Governor, 3 cases by the Deputy Regent, and 1 case by the Deputy Mayor (Data processed by researchers, 2020).

Indonesia Corruption Watch (ICW) calculated that at the beginning of 2018, there were IDR 569 billion in state losses of the total 1.09 trillion due to corruption. This finding is parallel to the data from the Ministry of Home Affairs, which until October 2018 recorded 434 people were governors, regents and mayors stumbled over legal problems at the prosecutor's office, police, and KPK. Furthermore, regarding the Ministry of Home Affairs data budget, from2004 to 2009, 241 local government leaders were involved in a corruption case, while in2009 to 2014 there were only 101 people. From 2014 to 2018, there were only 92 cases ensnared corruptors at the local level. The model of corruption that occurred is financial abuse of power in some areas managed by the regions themselves as part of the autonomy policy in Indonesia (Reza, 2018).

The large number of regional heads who have tripped over the problem of corruption seems to be related to the direct regional election which has spent a lot of money on the regional head candidates. During the

Received: 2020-03-27, Revised: 2020-04-15, Accepted: 2020-12-18

Print ISSN: 0215-8175; Online ISSN: 2303-2499. DOI: https://doi.org/10.29313/mimbar.v36i2.5866

Accredited Sinta 2 based on the decree No.10/E/KPT/2019 until 2024. Indexed by DOAJ, Sinta, Garuda, Crossreff, Dimensions 
Table 1

Corruption of Local Government Heads in Lampung Province

\begin{tabular}{|c|c|c|c|c|}
\hline No & $\begin{array}{c}\text { Name of Local } \\
\text { Heads }\end{array}$ & Case & Punishments & Fine \\
\hline 1. & $\begin{array}{l}\text { Satono } \\
\text { (Lampung } \\
\text { Timur) }\end{array}$ & $\begin{array}{l}\text { Corruption of Local Budget } \\
\text { (APBD) Lampung Timur for } 111 \\
\text { billion Rupiah }\end{array}$ & $\begin{array}{l}15 \text { years of } \\
\text { imprisonment } \\
\text { (fugitive since } \\
\text { 2012) }\end{array}$ & \\
\hline 2 & $\begin{array}{l}\text { Wendy Melfa } \\
\text { (Lampung } \\
\text { Selatan) }\end{array}$ & $\begin{array}{l}\text { Becoming a suspect since } \\
1 \text { Mei } 2012 \text {, corruption } \\
\text { of land procurement for } \\
\text { National Electric Company of } \\
\text { Sabalangfor } 26.6 \text { billion Rupiah }\end{array}$ & $\begin{array}{l}10 \text { years of } \\
\text { imprisonment }\end{array}$ & $\begin{array}{l}500 \text { million fine, } \\
14.3 \text { billion Rupiah } \\
\text { compensation }\end{array}$ \\
\hline 3. & $\begin{array}{l}\text { Andy Achmad } \\
\text { (Lampung } \\
\text { Tengah) }\end{array}$ & $\begin{array}{l}\text { Arrested on } 24 \text { Maret 2011, } \\
\text { Corruption of APBD 2008, } 28 \\
\text { billion Rupiah }\end{array}$ & $\begin{array}{l}12 \text { years of } \\
\text { imprisonment }\end{array}$ & $\begin{array}{l}500 \text { million fine, } \\
20.5 \text { billion Rupiah } \\
\text { compensation }\end{array}$ \\
\hline 4. & $\begin{array}{l}\text { Bambang } \\
\text { Kurniawan } \\
\text { (Tanggamus) }\end{array}$ & $\begin{array}{l}\text { OTT on } 21 \text { October } 2016 \text {, } \\
\text { bribery toDPRD Tanggamus } \\
\text { forlegalizing APBD } 2016\end{array}$ & $\begin{array}{l}2 \text { years of } \\
\text { imprisonment }\end{array}$ & 250 million fine \\
\hline 5. & $\begin{array}{l}\text { Zainudin Hasan } \\
\text { (Lampung } \\
\text { Selatan) }\end{array}$ & $\begin{array}{l}\text { OTT KPK on } 27 \text { July } 2018 \text {, } \\
\text { Corruption and money } \\
\text { laundering }\end{array}$ & $\begin{array}{l}12 \text { years of } \\
\text { imprisonment }\end{array}$ & $\begin{array}{l}500 \text { million fine, } \\
66,7 \text { billion Rupiah } \\
\text { compensation }\end{array}$ \\
\hline 6. & $\begin{array}{l}\text { Mustafa } \\
\text { (Lampung } \\
\text { Tengah) }\end{array}$ & $\begin{array}{l}\text { OTT KPK on } 15 \text { February } 2018 \text {, } \\
\text { Bribery toDPRD Lamteng for } 9.6 \\
\text { billion }\end{array}$ & $\begin{array}{l}3 \text { years of } \\
\text { imprisonment, re- } \\
\text { suspect for a case } \\
\text { of } 95 \text { billion Rupiah } \\
\text { gratification }\end{array}$ & 100 million fine \\
\hline 7. & $\begin{array}{l}\text { Khamamik } \\
\text { (Mesuji) }\end{array}$ & $\begin{array}{l}\text { OTT KPK on } 23 \text { January 2019, } \\
\text { Bribery case for project fee of } \\
\text { infrastructure inMesuji }\end{array}$ & $\begin{array}{l}8 \text { years of } \\
\text { imprisonment }\end{array}$ & 300 million fine \\
\hline 8. & $\begin{array}{l}\text { Agung Ilmu } \\
\text { Mangkunegara } \\
\text { (Lampung Utara) }\end{array}$ & $\begin{array}{l}\text { OTT KPK on } 7 \text { Oktober } 2019 \text {, } \\
\text { Bribery case for project fee of } \\
\text { infrastructure in Lampung Utara }\end{array}$ & $\begin{array}{l}7 \text { years of } \\
\text { imprisonment }\end{array}$ & $\begin{array}{l}750 \text { million fine, } \\
74 \text { billion Rupiah } \\
\text { compensation }\end{array}$ \\
\hline
\end{tabular}

Source: processed data by researchers 2020

socialization process and campaign period, the costs spent by the candidates for regents or mayors is around IDR 3 billion and 25 billion, while candidates for governors spent 8 to 20 billion (Agustino, 2017: 111).

Related research including Rumesten (2014) discusses a correlation between the corrupt behavior of regional heads and direct regional elections. Heriningsih (2013) elaborates the regional financial performance associated with the level of corruption: the healthier the financial performance, the lower the corruption occurs. Arifin's research (2019) inquire for the prevalence of licensing corruption associated with deposits prior to the regional elections. The relationship between corruption and political parties, with a discussion of the correlation of parties to corruption, was examined by Hanafi (2014) and Irham (2016). Patty's research (2019) more explicitly prohibits former corruption convicts from running for regional head again to suppress recurring corruption cases and social punishment.
Subarjo (2018) and Utami's (2018) research has a common thread that the implementation of decentralization in the regions cannot reduce the rate of corruption occurs. The regions are still controlled by local strongmen, strong people in local domain. Solihah's research (2016) has examined in advance the 2015 simultaneous regional elections that filled with transactional politics in all domains, including participants, contestants, regional head candidates, and voters. Regional heads who did ultimate corruption have an impact on government performance, as shown by the research results from Pahlevi (2017).

Klitgaardargues that corruption behaviour that is not in accordance with the rules of the mandate of public office position aims to seek an advantage in the form of money or other things and it usually involves kinship politics (Handoyo, 2015: 22). Corruption is closely related to the wide gap between the owner of power and the ruled people or communities, for 
example, bureaucrats and ordinary people (Kurniawan, 2018: 9-10). Corruption takes many forms: bribery, embezzlement, fraud, extortion, favoritism, and other illegal acts that detrimental the state (Agustino, 2017: 28). The anti-corruption discourse in Indonesia follows the boundaries concept set by supranational actors such as the World Bank and Transparency International, the $\mathrm{KPK}$, and the Indonesian Corruption Watch (ICW), which then adopts and applies these limitations in the country. Activities that were previously not known as corruption are no longer known as corruption today, In the context of Indonesia, this limit is not enough to control people's behavior (Pertiwi, 2019: 138). The researchers gave an example that giving gifts during the election of village heads is a common and permissible thing.

The complicated problem of corruption is often only a matter of the inability of a social actor to choose the right behavior in moral or ethical standards, whether it is due to wrong understanding or based on certain standards that apply across time and space (Pertiwi, 2019: 140). The argument of Pertiwi is similar to the anthropological factors based on the view of Agustino (2017).

Corruption is caused by two things: firstly, there is no reward and punishment mechanism in public services; secondly, there is no system with integrity. The concept of reward and punishment is closely related to the actors in the bureaucracy, how they respond, agree or disagree with the political will of politicians. A system with integrity is related to the belief that a human being who has integrity can control himself from corrupt behavior. (Pertiwi, 2019: 142)

Corruption is a form of uncooperative behavior where someone tends to abuse his/her power for prioritizing personal interests. The five components of corruption are deviant behavior, abuse of power and authority, committed to personal or group interests, violating the law and deviating from ethical and moral norms, which occurring in government or private agencies. (Mulyana, 2019: 246) Other factors that can cause someone to corrupt are psychological and non-psychological aspects. Corruptors are lower in terms of psychological aspects, particularly in personality and motivation, compared to other people who do not corrupt. Non-psychic aspects are other factors besides personality and motivation (Mulyana, 2019: 250-251).
This paper is the result of our study which analyzes the dominant factors that can cause corruption to increase significantly in Lampung Province, and the impact of the involvement of money politics or vote-buying in it.

\section{Research Methodology}

This study uses a qualitative method, which is a process of observation to understand a social problem based on a complete picture formed by words and seeking information from informant in detail based on the actual reality (Creswell, 2009: 4). The descriptive method is a condition to find a situation, condition, circumstances, and many other things that need to be recorded in a written report (Sugiyono, 2013: 3).

Data sources in this study are primary and secondary data. A primary source is an original object or document - the raw material from the actors - which is called first-hand information (Silalahi 2012: 289). Primary data in this study are obtained from interviews with informants. Secondary data is data collected from second sources or from other sources widely available before the research was carried out (Silalahi, 2012: 291). Secondary data in this study are documents.

Data analysis in this research passes three stages: first selecting, summarizing and transforming data; second, displaying data to be organized and concise; and finally making a decision (Miles, Huberman, \& Saldana, 2014).

\section{Results And Discussion \\ Anthropological Factor}

A negative natural circumstance in a person causes corrupt behaviour. This negative natural behaviour tends to be powerless against lust and the temptation of corruption. Many factors influence negative behaviour. The perspective of anthropological factors sees that weak moral tendencies, weak in faith, and an understanding of religious beliefs that are still half-hearted create conditions and comfort for corrupt behaviour.

One of the causes of corruption is a weak civil society and it is driven by negative inner nature due to the lack of moral strength in a regional head. A regional head who has power is usually corrupt, according to the famous quote from Lord Acton, "power tends to be corrupt, absolute power tends to be corrupt 
absolutely". Therefore, in line with factors that cause corruption, the researchers cite the opinion from Shore and Haller (in Agustino; 2017) who state that corrupt behaviour grows because of the deviant behaviour of rulers to seek something financial (Agustino 2017: 31).

The tendency to gain profit and hold the highest power raises the desire of corruption. It tends to be higher even though corruptors do not necessarily know the rules of right or wrong and the impact of corruption. Nasrumin his research argues that the position of boss has more possibilities for illegal personal enrichment and protection from lawsuits from lowly employees. Thus, the structural perspective emphasizes the strong relationship between corruption and unequal distribution of resources in society. (Nasrum, 2013: 7).

The results of our interviews with informants found that corruption can come from a variety of factors:

"All factors can influence corruption starting
from family, society, religion, maybe even
moral factors, such as the lack of religious
value" (Source: RL interview results; 15
November 2019)

Corruption can be caused by factors of family, the lack of religious morality, and moral. From an anthropological point of view, all of these factors come from the person himself/herself. Self-control becomes the subjectivity of individual himself, however, as social beings, humans are very prospective to be influenced by their environment so that self-confidence becomes weak in facing the temptations of corruption.

This statement is supported by the opinion of another informant, namely a youth leader in Lampung, who stated:

\footnotetext{
"Corruption can occur because human resources themselves have a lack of moral principle so that they are easily tempted; they understand that corruption is wrong, but they still do that anyway" (Source: BA interview results; 24 November 2019)
}

The lack of principles and morals in individuals cause a person to behave corruptly. Consciously, the corruptors, especially regional heads in Lampung Province who have a high level of intelligence (mostly undergraduate and even postgraduate), understand that corruption is a despicable activity and it is against the law. The regulations regarding state finances for regional heads have also been understood by them, but it can still be circumvented. Environmental conditions make corruption easy to occur. Regional heads in
Lampung still feel that corruption is not a despicable action because many corruptors in other areas have not been exposed, and even many cases have been disappeared during the investigations.

Based on our data, there were only eight (8) regional heads that have convicted of corruption, four (4) of four were caught through sting operations in the last two years (data are in table 1). The eight of regional heads are all head regents of Lampung Timur (East Lampung), Lampung Selatan (South Lampung), Tanggamus, Mesuji and Lampung Utara (North Lampung) districts. Six districts in Lampung Province(40\%) of regional heads at the level of a Regent/Mayor have done corruption.

In addition, Lay argues that corruption is the oil lubricant of democracy; without corruption, development will not run properly. "Corruption revives the pillars bones of government to move because government actors are accustomed to corrupt"(Lay, 2009 in the Indonesian Politics subject, Postgraduate Fisipol UGM)". The lack of personal morality factor that is weak against the culture of corruption in the Lampung province is worsened by the absence of behaviour controlling tools. Social control can be found in the power of civil society, but they are also powerless to prevent corruption committed by regional heads. $\mathrm{RL}$, our other informant, reinforced the statement by saying:

"The regional head in the context of government administration as the highest authority holder in the area has a high desire and opportunity to corrupt; that is what happened in Lampung, including in the region. Civil society in Lampung is not strong, now that is also a significant factor for corruption" (Source: RL interview results November 14, 2019).

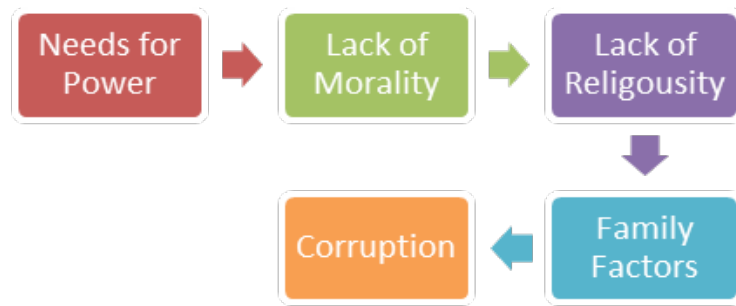

Graphic 1. Anthropological Factors of Corruption among the Heads of Regions in Lampung Province

Source: Data is gathered in 2020

\section{Political Economy Factor}

Pilkadaor local election requires a lot of money, where regional head candidates at the beginning of their candidacy will firstly spend funds which usually come from their 
own pockets. If private funds are insufficient, candidates will look for a deputy regional head candidate who has a huge amount of money. They usually come from business persons. The debt of gratitude, if they are elected, will be fully paid by the head of government with fee or bribe from regional procurement projects. These projects are sources of corruption in the regions.

In Indonesia, we call political party who give endorsement for the running candidate as "political boat". The boats of political parties cannot be considered as independent variables. The candidates give money to political parties as political party rental fee. It is the dependent variable for regional head candidates. Fee for political parties is a common thing as a consequence of supporting nominations. The fee for each political party is different. It is based on the number of seats and volunteer assistants who are directly involved in the winning campaign. Funds for campaigns are completely handed over to candidates for the head of district, so that the campaign variables have a large correlation with funding. In addition, the winning team funds with all the risks are used for paying billboards, banners, pamphlets, and giving compassion to constituents of voters such as basic necessities, goods, money and activity programs if the candidates are being selected. The biggest political economy factor is the high political cost, especially during regional elections.

Another informant comes from a politician of Bandar Lampung City. He highlighted the possibility of high political cost as the main reason why there are so many corruption of regional head in Lampung. He said:

\begin{abstract}
"Our politics is high costs politics, and we can confirm in quotation marks that there are a lot of money in circulation and it is unclear in the context of the current election. The costs spent to run for regional head are huge. There is a long process to go through to participate in the Pilkada. Political investment to win the elections requires high costs: the success team process cost, political broker, buying and selling political party boats, and other costs. Like it or not, the head of the region, even though he is not profitable, he has to return this cost, whether they owe the money or not, we don't know, "(Source: IR interview results, 20 November 2019)
\end{abstract}

Regulatory loopholes are usually related to veiled political spending or hidden political spending done both by candidates and campaign teams where the money used for camouflaging political spending is called dark money (Prasetyo 2019: 16). Dark money is several funds donated to political parties, candidates or campaign teams that are used for political spending to influence elections. The fund is needed for the nomination process to participate in local election in the next period or compensating previous local election funds. The long campaign process in regional head elections costs high expenditure of funds. The increase of election costs is also absorbed by the costs during the campaign period. A candidate who is promoted by a political party usually spends his/her budget for operational activities.

In addition, in the context of democratic transition, Kurniawan (2018) argues that we can find large numbers of corruption in the transitional countries of the new democracy. While the political structure has shifted to the democratic system, the system of authoritarian institutions in law persists. Democracy fosters rent-seeking activity among businessmen and politicians. Politicians need money to win elections, and businesspeople provide money for the politicians. After the politicians are elected, they pay back the money to businesspeople in the form of privileges and benefits from state policies. As a consequence, elected politicians do not care about the interests of their constituents, such as poverty eradication, improvement of healthcare and education. They only think about how to pay back the costs of the election they have spent. This reality is not democracy but plutocracy, the term from Aristotle refers to the domination of rich people in controlling the government. The other effect of rent-seeking is oligarchy. Indonesia, after an authoritarian regime, shows that most of the political elite and leaders focus on debating against each other and how to obtain power rather than how to develop Indonesia's economy. Hadiz and Robison (2004 cited in Kurniawan 2018) argue that after the Soeharto period, true democracy never occurred. The business oligarchy's influence took over Indonesian politics rather than the politicians and civil society did.

The tight competition in obtaining letters of support or endorsement from political parties causes candidates to be forced to take shortcuts way by paying in advance before the election. It is usually called as a political dowry or boat rental (Adelina, 2019: 70). This practice which is categorized as bribery to political parties is costly and it drains "the pockets" of the candidates, even though not 
all candidates have large capital. The results of further research claim that transactional politics before the election does not only occur for executive and legislative candidacy but also for multi-stakeholder in the region. This political transaction is neat coordination involving many parties as the actors.

Mathematically, the regional head's monthly income is not sufficient for him to cover all the political costs of a regional head election. Researchers quote from an informant, a community leader who is also a politician in Central Lampung: "Let's count, if you want to return the campaign
cost, and you don't have money, the desperate
way is to definitely mark up the budget item.
The mayor regent's salary maybe around 60 or
70 million per month with some allowances. If
you have been in the office for five years, only
3.6 billion will be collected with a maximum
of 4.2 billion. Hey, the campaign costs could
be more than that ... (laughs) ... (Source: SS
Interview, 19 November 2019).

The cost for" renting a boat" of political parties, campaign activities, survey costs and logistics are all covered by the regional head candidates. Funds are obtained by seeking political investors from entrepreneurs, and usually with some promises that they will get special privileges such as infrastructure projects in the regions, regulatory support and so on. This is what Aspinall (2015) identifies as vote-buying or money politics.

This gift is usually an effort to repay investors for their assistance in providing campaign funds for regional head candidates. Corruption is an activity done in congregation (together) with secret acts to get financial benefits (Handoyo 2015: 27). Some factors of political corruption do not stand alone; there are other factors such as trying to enrich themselves (all parties involved), funding political parties, funding political activities and political interests of their elections, or even the combination of these factors. These various factors can be identified based on what or where the corruption money are transferred from.

The collaboration with private sector is a factor that causes corruption in the form of gratuities from companies with the main goal to get a road construction project. In Mustafa's case, for example, the money received from the company was then given by Mustafa to members of the Central Lampung Regency DPRD so that they will approve planning for borrowing money from BUMN companies in order to accelerate the infrastructure development in Central Lampung Regency. This fund will also be used for the operation of the Governor's nomination.

The opinion of a bureaucrat in Lampung Tengah regarding the corruption done by Mustafa which occurred just before the election for the Governor of Lampung in 2018 is as follows:

"In Central Lampung, the factor of corruption occurs due to the ongoing project of "Ijon" (forecast payment in advance) process, but entrepreneurs are asked for a lot of money as campaign capital while the project itself has not yet been implemented since the new APBD structure will start in May. Meanwhile, the campaign should have been running from April until May. It takes a long time to campaign from the KPU; it is understandable not to use the state money if it is not for the officials, but the regional head might use the state budget "(Source: SR interview results, 22 November 2019)

Regional head corruption also occurs when DPRD members are able to "help" the region to obtain additional funds by accelerating the disbursement of the APBD budget. As a "reward" for their assistance, members of the DPR get the "fee for processing/manage it". Management funds or what is commonly referred to as fees are requested in advance, so it is common for regional heads who want to be assisted in the management and disbursement of funds to collect a number of "fees". In Mustafa's case, it is can be called as commitment fees from partners to collect money requested by DPRD members. These commitment fees from partners are obtained through the Head of the Office (Kepala Dinas). This model also occurred in the corruption case of Regent (bupati) Bambang Kurniawan, which involved dozens of members of the Tanggamus Regency DPRD in 2016.

When the regional head cannot provide the amount of money requested, he will ask for help from entrepreneurs in his area to provide funds. The regional head accepts bribes from entrepreneurs based on sharing road construction projects in his area. The impact of this cooperation is that the regional head will be forced to sign an agreement with the entrepreneur in many ways, one of which is to give a priority in procurement tender so that the regional head can repay his political debt to the companies. This corruption model also happened to Khamami, Mesuji Regent, and Mustafa (Regent of Lampung Tengah).

Corruption cases involve many parties, including businessmen, DPRD members and 
the bureaucracy. Bureaucratic institutions become an arena for bargaining strategic interests of political elites who usually sell the political influence of public interests that require some power of influence from political elites, bureaucratic institutions such as ministerial agencies, police, agencies and so on (Agustino, 2017: 64). Government elites, bureaucrats, and politicians manipulate bureaucratic networks for profit for two purposes; the election and the voters (Agustino, 2017: 65-66).

Their income as a regional head is still not sufficient to cover the high political costs of campaign. Moreover, for funding their activities, regional head candidates have to borrow money from their relatives. A political party that gallantly says that there is no "dowry politics" in a campaign, we see it as a sweet talk campaign to make voters believe and give their vote to the party.

The laws and regulations in Indonesia do not allow political parties to seek their income, so the most practical way is to charge the candidates a fee.

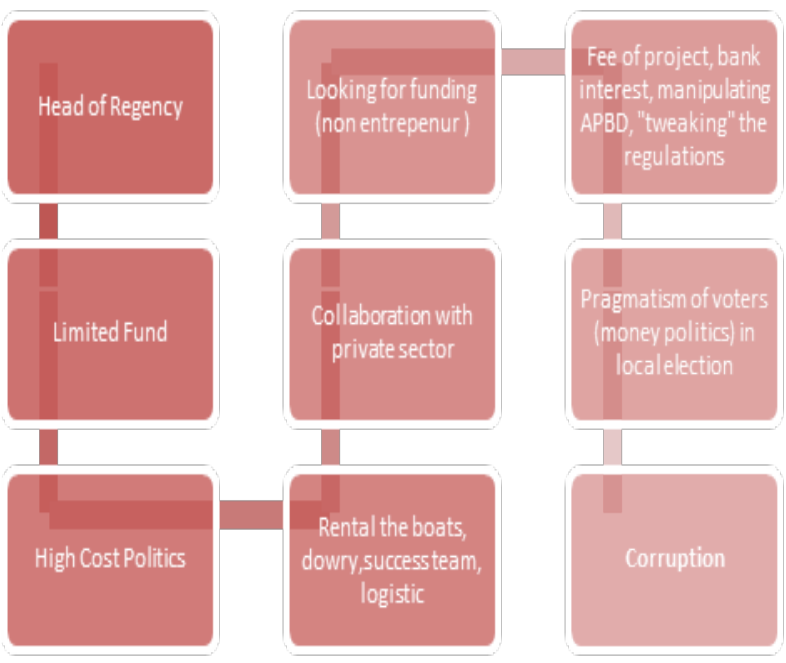

Graphic 2. The flow of political economy factor of why corruption occurred at the regency (done by the regent) in Lampung Province

Source: Data gathered in 2020

Some factors causing regional head corruption include repaying the money to cover campaign costs because regional head candidates often have to borrow the money, or they are tied to hidden cooperation with the private sector as a consequence for receiving campaign funding from them. This model of political situation happened in Lampung, even in all regional heads that were involved in corruption as shown in Table 1 . This is the impact of high political costs. Ironically, there was only small part of this cost which is covered by political parties that they support as candidates for regent and vice-regent in local elections.

Money politics and the high cost of politics in elections are political economy factors that cause corruption. There is a simple logic with mathematical formula of economics behind this. The expenditure must be covered by income; if the expenditure exceeds the income limit, new income will be created to cover and even get the benefit from the expenditure that has been spent. As a result, the logic of corruption can be identified based on this explanation. We can see in graphic 2 .

\section{Sociological Factor}

Sociological factors are closely related to the circumstances around political arena. In the sociological concept, according to the authors' opinion, the circumstances can come from family social environment, neighbourhood, association, social relations, association, common interests, and common lifestyles that can create collective group awareness. When a group has created a pattern of association and equality in life, group members will adhere to the predetermined group standards. For example, a standard of living a luxurious lifestyle in a certain society, in which to meet these standards it is common for the members of that society to commit corruption as a quick solution for it.

We interview some informants to confirm this factor. A community leader in Tanggamus Regency explains that lifestyle and social environmental factors can drive someone to commit corruption. He said:

"... actually, the regent's salary is more than enough, but if it is related to the lifestyle, it is clearly not enough. The lifestyle of celebrities, luxury goods and vehicles, luxury homes, overseas trips, even though many of their people don't earn enough to get food. The lifestyle and views from the community also influence it. The community thinks that it is not common if the regent does not have a car, if the regent has only a small house, so that it inevitably arises a desire to live a regent standard. In Lampung language, we call it aspiil (ego)"(Source: RY interview results, 1 December 2019).

The mushrooming of money politics in Lampung create a number of corruptions of regional heads in Lampung when the local elections approaching is caused by the 
desire and openness of the community is expecting gifts or rewards from regional head candidates. This response is a repetition of a similar response from the 2005 regional elections. The culmination happened in the 2014 general election. Some indications showed that there was no significant decrease in the 2019 elections, especially in Lampung province.

The organizational circumstances can also influence someone to corrupt. We see that anyone can be involved in corruption, both superiors and subordinates. If a leader does not have exemplary and integrity, this can be imitated by his subordinates. Corruption in Lampung is an interesting phenomenon because several regional heads have been caught doing corruption through OTT by the $\mathrm{KPK}$. This corruption is not only created by corporations and DPRD members, but also by bureaucracy. We can see in graphic 3 .

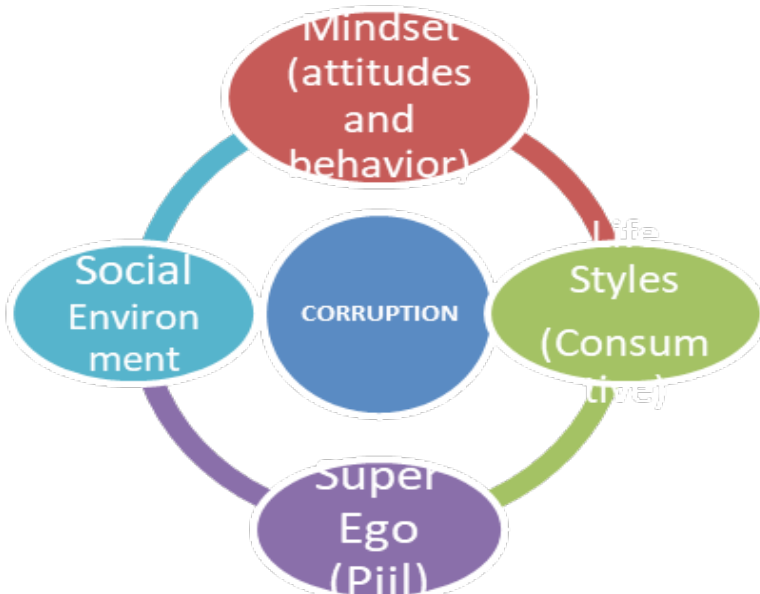

Graphic 3: Sociological Factor of Regional Head Corruption in Lampung Province

Source: Data gathered in 2020

\section{Repeat Corruption}

The three factors above, including anthropological, sociological, and political economy factors, are the causes of rampant corruption of regional head in Lampung Province. The question that arises is why corruption is always repeated in Lampung Province even though many regional heads have been convicted? The answer lies in the ego or superego of the regional head in Lampung Province. The positions of regional heads (governor, regent, mayor) and even prestigious positions in the government bureaucracy are the ideals of many Lampung residents.

Lampung culture gives excessive appreciation and glorifies someone who has a political position or a position in the government bureaucracy. This culture has been embedded for a long time from the time of the local kingdom in Lampung and Dutch colonialism where the natives who have positions in government have a high social status in the Lampung society.

Lampung has a tradition called "cakak pepadun" (rising to a high place). Cakak in Indonesian means to rise, pepadun is a bench or throne made of beautifully carved wood which is a symbol of social status in Lampung society.

This 'cakak pepadun' procession means that someone from an ordinary family (does not have a customary title) can get a customary title (sultan, prince or other given title) both men and women through custom processions by traditional elders. The cultural procession costs a lot of money so that only certain people who have money can do it. The customary title obtained makes a person's status higher among indigenous people.

The corruption mostly done by regional heads in Lampung Province, according to the authors' opinion, is related to ego or superego, or in Lampung language, it is called "piil". Piil is the pride of Lampung people, which according to customary rules is positive, but in practice is negative because one's self-esteem is associated with social status, economic status and position in both political and government positions.

Eight regional heads in Lampung Province who have been trapped by corruption through 'Operasi Tangkap Tangan (OTT)' are an example that corruption is an act that has become commonplace. This action is exacerbated by ego or superego or in Lampung's language is called personal 'piil' of the regional head that in order to get attention and legitimacy from the public as a regional head, he must show his all-natural identity more than ordinary citizens, especially in terms of wealth, prestige, authority and power.

\section{Money Politics}

Money politics in the 2019 elections are similar to the 2014 elections; structured, systematic and massive. The 2019 election is more competitive than the previous ones since the parliamentary threshold has increased from 3.5 percent to 4 percent. 
Money politics in the form of political dowries given by prospective candidates to parties as well as by parties to legislative candidates and buying and selling of votes are widely said to have occurred in the 2019 elections. Bawaslu (election supervisor institutions) said that election violations that had been decided in court until February 2019 were dominated by vote-buying. (Sjafrina, 2019: 48)

The direct election system and open list proportional legislative electoral system were accused as the main source of these problems, even though other systems were not free from money politics (table 2 ). Some improvement is needed, such as in recruitment process, funding of political parties, and political education for voters. Political dowry is motivated by funding problems and party committees since all political parties or elements and party elites make elections as a raising funds activity. Candidacy tickets from political parties are the main requirement for anyone to get seats in the legislative, regional heads, presidents and vice presidents. (Sjafrina, 2019: 49).

In the corruption case involving 4 regional heads who were OTT by the KPK, such as in the case of Mustafa, Zainuddin Hassan, Khamami, and Agung IlmuMangkunegara, there are several indications of corruption that can be seen which will be elaborated below.

First, replace the political costs as a consequence of the high (cost) political contestation. In another sense, corruption occurs because political elites have to pay high political costs in order to win general elections, as well as to keep the loyalty of their constituents. From this case, it can be seen that high-cost politics have become a tool for committing corruption again and again. It becomes a link in the corruption chain that produces a series of corruption cases that continue to emerge endlessly. As an impact, the problem of corruption becomes a systemic problem.

Second, the patronage or patron-client mechanism is the result of unhealthy political contestation. Patronage is caused by the powerlessness of the clients in front of the patrons. The patrons who have the resources can control the clients who have nothing; Mutualistic symbiosis relationship arises when the client needs a reward for the assistance requested by the patron. This model is also included in political institutions including the executive, legislative, and judiciary (Kitschelt, 2007: 60).
We can identify this model from the corruption cases of 4 regional heads(Mustafa, Zainuddin Hassan, Khamami, and Agung IlmuMangkunegara) in sting operations(OTT) by the KPK. It is a model of patronage or patron-clients involving people trusted by the regional head to receive funds from partners. The case in South Lampung was based on investigators' investigations involving Agus Bhakti Nugroho as a confidant of the South Lampung Regent, Zainuddin Hasan, to receive money or act on behalf of the regent.

Another example comes from Mesuji. Sibron Aziz and Kardinal as the perpetrators of bribery gave 1.580 billion Rupiahs or 12 percent of the project value to Khamami, the Mesuji Regent, in order to get an infrastructure project at the PUPR (Ministry of Public Work and Housing) of Mesuji Regency. Bribes were gradually given over a short period. First, it was given in May 2018 of 200 million Rupiahs; second, in August 2018 of 100 million Rupiahs; and most recently in December 2018 of around 1.28 billion Rupiahs.

Third, selling the influence or power they have as political elites. The strategic position of the elite causes the political elite to have special rights; they can use their power, influence, or position to play a role as a distributor of power, interests, wealth, and so on to public who need it. The regional head has the authority as a budget user and policymaker to regulate who has the right to sit in a position that is easy for receiving bribes without supervision from other parties, but in practice, this authority is abused for receiving projects and taking advantage by cutting the budget.

Bureaucracy is fragile with corruption. It is caused by an internal locus such as a weak supervision system from superior-top position to its subordinate. The external locus is the relationship between various related systems in the form of co-optation and political intervention. Political pressure is one of the reasons of corruption, for example, pressure from regional heads to the bureaucracy. The process of placing positions is closed and based on political affiliation, especially the success (campaign) team in the regional elections (Irawati, 2013: 102).

Another factor causing the rise of corruption in both local and central areas is the permissive culture by the community which makes bribery and gratuities in services and elections become a common culture. Candidates with bad track record, such as 
Table 2

Money Politics in Corruption of Regional Heads in Lampung Province

\begin{tabular}{|c|c|c|}
\hline High Political Cost & Patron-Client Politics & Selling Power \\
\hline $\begin{array}{l}\text { The high political cost and } \\
\text { political dowry to buy a boat } \\
\text { (political party) }\end{array}$ & $\begin{array}{l}\text { The patron-client factor } \\
\text { becomes an influence for } \\
\text { regional heads to commit } \\
\text { corruption with the agreement } \\
\text { of their subordinates or trusted } \\
\text { people (client) }\end{array}$ & $\begin{array}{l}\text { Regional heads have special } \\
\text { legitimacy in their regional } \\
\text { autonomy. This means that full } \\
\text { power is in his hands }\end{array}$ \\
\hline $\begin{array}{l}\text { Unclear money circulating } \\
\text { within the scope of the } \\
\text { democratic process (pilkada) }\end{array}$ & $\begin{array}{l}\text { In the cases and facts of } \\
\text { the court, every corruptor in } \\
\text { Lampung involved his family in } \\
\text { accepting bribes }\end{array}$ & $\begin{array}{l}\text { The regional head has powers } \\
\text { that he can misuse; if someone } \\
\text { who is his subordinate wants a } \\
\text { certain position, then he must } \\
\text { give a certain amount of money } \\
\text { to the regional head so that he } \\
\text { can get that position. }\end{array}$ \\
\hline $\begin{array}{l}\text { At a minimum level, the } \\
\text { regional head returns the } \\
\text { election fund for his pilkada } \\
\text { candidacy with the hope to get } \\
\text { more profits }\end{array}$ & $\begin{array}{l}\text { In the bureaucracy, if someone } \\
\text { wants to sit in a strategic } \\
\text { position, he must also provide } \\
\text { benefits for the regional head }\end{array}$ & $\begin{array}{l}\text { Regional heads have the ability } \\
\text { as budget users to regulate who } \\
\text { has the right to sit in a position } \\
\text { that easy to receive bribes } \\
\text { without supervision from other } \\
\text { parties }\end{array}$ \\
\hline $\begin{array}{l}\text { Vote buying and money } \\
\text { politics; giving money, goods, } \\
\text { gifts, political promises, } \\
\text { project promises }\end{array}$ & $\begin{array}{l}\text { Money politics by making the } \\
\text { family a successful team with } \\
\text { the promise of a job or project }\end{array}$ & $\begin{array}{l}\text { Money politics by giving political } \\
\text { power (position) to the success } \\
\text { team, especially the family }\end{array}$ \\
\hline
\end{tabular}

Source: Data from 2020

ex-convicts, suspects, corruption defendants, moral flaws with deviant sex behavior, will be remain elected if their 'branding' is good in package (Kurniawan, 2017).

The model of power trading or influence selling is done by the regent by pressuring his subordinates for seeking or getting operational funds for the elections or campaign process. The heads of office who do not agree will be kicked from his position, and the head of regent will find other bureaucrats who can serve the interest of the Regent; this is common and still happens today in Lampung Province.

\section{CONCLUSION}

The causative factors of regional head corruption consist of anthropological factors, economic factors, and sociological factors. These three factors have their influence on the corruption behavior of regional heads, especially in Lampung province. Anthropological factors are based on the self-awareness of each regional head. The average regional head in Lampung province comes from an upper class, although there are a few of them who come from middleclass families. They struggle and gain power in the electoral mechanism. Personal factors that are sensitive to lust and temptation for profit become the cause of corruption.

The sociological factors in the corruption of regional heads in Lampung province are limited in term of following the lifestyle and social status of regional heads. As a result, it increases their bargaining power to the people and their subordinates in the government bureaucracy. It is also to show a similar status with other regional heads, especially in terms of lifestyle.

The most influential factors in this study were economic factors. Economic factor means the number of funds including the cost of the parliament's rent, campaigns, winning teams and vote-buying. These kinds of corruption model were committed by candidates in order to cover political cost that had already been spent. They cover it from the benefit they will get when they are being elected. Corruption is done in several ways: by giving bribery on the government projects to the members of DPRD (local parliament), receiving gratuities from companies and partners, requesting 
project fees, doing financial manipulation, and doing vote-buying.

Money politics or vote-buying are done by giving goods, gifts, job promises, project promises to voters, partners, corporations or bureaucracy during the election campaign of regional heads. These high political costs include political dowry to parties, capital, and vote-buying. The politics of patronage is also significantly played by engaging subordinates, bureaucracy, and close family. Selling power was carried out by buying and selling the position of the head of office, and other bureaucratic positions. It also gives power to successful teams, especially families by involving them in infrastructure projects tender of the local government.

This paper recommends that there is a need for changes to the bad environment in regional head elections, especially in Lampung Province. The bad environment includes anthropological, sociological and economic factors. The author suggests revising 'Undang-Undang No. 10 tahun 2016' on regional head elections by reducing the percentage of political party support from $20 \%$ to $10 \%$ so that the number of candidate pairs will increase and have an impact on reducing the corruption to buy some chair of political party.

Project bonuses (fees) that become lahan basah (lucrative positions/jobs/working fields with great chances to commit corruption) must be supervised by the commission of 'Komisi Pemberantasan Korupsi (KPK)' and the judiciary. Civil servant (ASN or PNS) are neutral, auctions with a merit system are mandatory without involving the regional head. Efforts are needed to strengthen the commission (KPK) to exist in every province (representative), increase the punishment for corruptors up to the highest penalty (death penalty) and reverse proof of assets owned, as well as social penalties regulated by law.

\section{References}

Adelina, F.(2019). Bentuk-bentuk Korupsi Politik, Jurnal Legislasi Indonesia. Universitas Bung Karno, 16 (1), 21-31

Agustino,L\&Fitriani, I (2017).Korupsi: Akar, Aktor, dan Locus, Yogyakarta, PustakaPelajar.

Arifin, M. Z.\&Irsan (2019). Korupsi Perizinan Dalam Perjalanan Otonomi Daerah di Indonesia, Jurnal IImu Hukum: Lex Librum, 5(2),887-896
Aspinall, E., \&Sukmajati, M. (2015). PolitikUang di Indonesia, Patronage dan Klientelisme pada Pemilu Legislatif 2014. Yogyakarta: PolGov UGM

Creswell, J.W. (2009). Research Design :Qualitative, Quantitative, and Mixed Methods Approaches (Third Edit). California: Sage Publications,Inc

Hanafi, R.I. (2014). Pemilihan Langsung Kepala Daerah di Indonesia: Beberapa Catatan Kritis Untuk Partai Politik, Jurnal Penelitian Politik 11 (2), 1-16

Handoyo, E. (2015).Pendidikan Anti Korups iEdisiRevisi, Semarang, Penerbit Ombak (Anggota IKAPI).

Heriningsih, S. \& Marita. (2013). Pengaruh Opini Audit dan Kinerja Keuangan Pemerintah Daerah Terhadap Tingkat Korupsi Pemerintah Daerah, Jurnal Manajemen, Akuntansi dan Ekonomi Pembangunan, 11(1), 67-78.

Irawati. (2013). Kearifan Lokal dan Pemberantasan Korupsi dalam Birokrasi, Jurnal MIMBAR Unisba, 29 (1), 101-110

Irham, M. A. (2016) Korupsi Demokratis dalam Partai Politik, Jurnal Sosiologi: Masyarakat, 21(1), 35-56

Kitschelt, H. \& Wilkinson, S.I. (2007). Patrons, Clients, and Policies: Patterns of Democratic Accountability and Political Competition, Cambridge University Press

Kurniawan, A.(2018).Korupsi Membuka Paradox Perilaku Korup Dari Dimensi Etika Dan Keperilakuan, Yogyakarta, C.V Andi Offset.

Kurniawan, R.C.(2017). Bahaya Nalar Permisif Pemilih Dalam Pemilu, https://news. detik. $\mathrm{com} / \mathrm{kolom} / \mathrm{d}-3464381 /$ bahaya-nalarpermisif-pemilih-dalam-pemilu, Selasa, 04 April 2017.

Lay, C. (2009). Materi Perkuliahan Politik Indonesia, PascaSarjana S2 IImu Politik Fisipol UGM

Miles, Huberman, Saldana, J. (2014). Qualitative Data Analysis A Methods Sourcebook Third Edition. USA: Sage Publications.

Mulyana, A. et all. (2019) Social Value Orientation on Corruption Prisoners. Jurnal MIMBAR Unisba, 35(1), 245-252

Nasrum, M.(2013).Tentang Kata Korupsi yang Datang Silih Berganti:Suatu Penjelasan Budaya. Jurnal Antropologi Indonesia. 34 (1).

Pahlevi, A.R.\&Setiawan, D. (2017). Apakah Karakteristik Kepala Daerah Berdampak Terhadap Kinerja Pemerintahan?, Jurnal Akuntansi Multiparadigma,8 (3), 571582, http://dx.doi.org/10.18202/ 
jamal.2017.12.7074

Patty, J.M. (2019). Pelarangan Mantan Terpidana Korupsi Menjadi Calon Kepala Daerah Agar Menimbulkan Efek Jera, Jurnal Belo 5(1), 1-9, https://doi. org/10.30598/belovol5issue1page1-9

Pertiwi, K. (2019). Kesenjangandalam Wacana Antikorupsi di Indonesia: Temuan dari Literatur Studi Korupsi Kritis, Jurnal Antikorupsi INTEGRITAS KPK: 5 (2), 133-150

Prasetyo,W.(2019). Optimalisasi BekerjanyaP engungkapan Dana Kampanye sebagai Strategi Pencegahan Politik Uang,Jurnal Antikorupsi INTEGRITAS KPK, 5 (1), 15-27

Reza, J. (2018). Catatan ICW soal Penindakan Kasus Korupsi Semester 12018. https://nasional.kompas.com/ $\mathrm{read} / 2018 / 09 / 18 / 15475381 / c a t a t a n-$ icw-soal-penindakan-kasus-korupsisemester-i-2018

Rumesten, I. (2014). Korelasi Perilaku Korupsi Kepala Daerah Dengan Pilkada Langsung, Jurnal Dinamika Hukum Unsoed, 14(2),350-358http://dx.doi. org/10.20884/1/jdh.2014.14.2.302

Silalahi, U. (2012). Metode Penelitian Sosial. Bandung: PT. Refika Aditama.
Sjafrina, A.G.P. (2019) Dampak Politik Uang Terhadap Mahalnya Biaya Pemenangan Pemilu dan Korupsi Politik Jurnal Antikorupsi INTEGRITAS KPK, 5(1), 43-53

Solihah, R. (2016), Politik Transaksional Dalam Pilkada Serentak dan Implikasinya Bagi Pemerintahan Daerah di Indonesia. The POLITICS: Jurnal Magister Ilmu Politik Universitas Hasanuddin, 2 (1), 97-109

Subarjo, N. (2018). Peran Pemilihan Umum Kepala Daerah Dalam Mewujudkan Kepala Daerah Bebas Korupsi, Jurnal Mimbar Administrasi, 2(1), 43-53

Sudana,M.(2006). Good Governance Pengelolaan Anggaran Pemerintah Daerah (APBD) dan Implikasinya .Jurnal Lingkungan dan Pembangunan Wicaksana, $15(2), 150-158$

Sugiyono. (2013). Metode Penelitian Kuantitatif, Kualitatif dan R\&D. Bandung: Alfabeta.

Utami, I.S. (2018). Desentralisasi, Korupsi dan Tambal SulamPemerintahan Daerah di Indonesia, Jurnal Pendidikan Kewarganegaraan 5 (1), 35-46, http:// dx.doi.org/10.32493/jpkn.v5i1.y2018. p35-46. 